Article

\title{
Land Use and Land Cover Change Detection and Prediction in the Kathmandu District of Nepal Using Remote Sensing and GIS
}

\author{
Sonam Wangyel Wang ${ }^{1}$, Belay Manjur Gebru ${ }^{2}$ (), Munkhnasan Lamchin ${ }^{2}$, \\ Rijan Bhakta Kayastha ${ }^{3}$ and Woo-Kyun Lee ${ }^{2, *}$ \\ 1 Ojeong Eco-Resilience Institute (OJERI), Division of Environmental Science and Ecological Engineering, \\ College of Life Sciences, Korea University, Seoul 02841, Korea; wangsonam@gmail.com \\ 2 Division of Environmental Science and Ecological Engineering, College of Life Sciences, Korea University, \\ Seoul 02841, Korea; arsemabm@gmail.com (B.M.G.); nasaa@korea.ac.kr (M.L.) \\ 3 Department of Environmental Science and Engineering, Kathmandu University, Dhulikhel 6250, Nepal; \\ rijan@ku.edu.np \\ * Correspondence: leewk@korea.ac.kr
}

Received: 25 March 2020; Accepted: 2 May 2020; Published: 11 May 2020

\begin{abstract}
Understanding land use and land cover changes has become a necessity in managing and monitoring natural resources and development especially urban planning. Remote sensing and geographical information systems are proven tools for assessing land use and land cover changes that help planners to advance sustainability. Our study used remote sensing and geographical information system to detect and predict land use and land cover changes in one of the world's most vulnerable and rapidly growing city of Kathmandu in Nepal. We found that over a period of 20 years (from 1990 to 2010), the Kathmandu district has lost $9.28 \%$ of its forests, $9.80 \%$ of its agricultural land and $77 \%$ of its water bodies. Significant amounts of these losses have been absorbed by the expanding urbanized areas, which has gained $52.47 \%$ of land. Predictions of land use and land cover change trends for 2030 show worsening trends with forest, agriculture and water bodies to decrease by an additional $14.43 \%$, $16.67 \%$ and $25.83 \%$, respectively. The highest gain in 2030 is predicted for urbanized areas at $18.55 \%$. Rapid urbanization — coupled with lack of proper planning and high rural-urban migration-is the key driver of these changes. These changes are associated with loss of ecosystem services which will negatively impact human wellbeing in the city. We recommend city planners to mainstream ecosystem-based adaptation and mitigation into urban plans supported by strong policy and funds.
\end{abstract}

Keywords: Kathmandu; land use and land cover; urbanization; remote sensing

\section{Introduction}

At the crossroads of the twenty first century, threats from climate change, increasing frequency of disasters and other unknown potential effects of global environmental change continue to arrest human progress in achieving the sustainable development goals. Yet, ironically, human activities have been proven to be responsible for driving these changes resulting in modified landscapes that negatively impact ecosystem services and human wellbeing [1-4]. Major drivers of global environmental change include, but are not limited to, rapid urbanization [5,6], increasing population [7] and other socio-economic development activities resulting in deforestation [8], biodiversity loss [9], encroachment into arable agricultural land [10] and water resources. Further, scientific studies [11-13] also confirm that landscape changes are significantly associated with biodiversity loss, degrading water quality and increased carbon emissions as well as other detrimental impacts on aquatic and terrestrial ecosystem. For instance, large areas of agricultural and forestry land that were converted into urban land, mining 
quarries, and mega industrial estates were characterized by poor biodiversity, loss of ecosystem services, and thus prone to land degradation $[14,15]$. In addition, numerous studies $[16,17]$ have also reported that land cover changes impact radiative, thermodynamic and hydrological processes that can lead to changes in local climate. Such changes can create a more variable environment that are more susceptible to global temperature change, as well as increase the vulnerability and reduce resilience of communities, ecosystems and places to climatic stresses [13,18].

Teketay [2] asserted that landscape change is one of the most important indicators for understanding the interaction between humans and the environment. Understanding and monitoring the dynamics of land use and land cover changes, their intensity, direction, drivers, and impacts provide useful information for sustainable development planning $[19,20]$ and therefore remains an important goal in the field of land cover change science. Remote sensing in combination with GIS technology has been proven to provide scientifically credible results and policy recommendations that have assisted decision-makers and planners to advance sustainable development especially in fast growing urban settings [21]. As a result, remote sensing and GIS have become popular tools for better understanding of spatiotemporal and spectral characteristics of land use and land cover changes at local and global scales [22,23]. Geospatial modeling analysis that lies at the heart of these techniques [22,24] attempts to detect where the changes occurred or will potentially occur [25]. Most of these models use historical land use data to assess the past land transformation and transition, which in combination with environmental variables can predict future land use scenarios [26]. Predicted land use changes exhibiting major modifications and alternations can help land use planners, resource managers and conservation officers in promoting sustainable land management and mitigating negative impacts. Consequently, detecting and predicting land use changes have become an important consideration in variety of fields including, modeling rural and urban plans [27,28], identifying biodiversity hotspots for prioritizing conservation efforts, studying desertification dynamics, etc. [29]. Geospatial analysis uses various statistical and rule-based modeling approaches for detecting and predicting land use changes [30]. Commonly used models in land use and land cover change (LULC) studies include; statistical models [31], evolutionary models [32], cellular models [33], Markov models [34], hybrid models [35], expert system models [36] and multi-agent models [37]. Of these, the most popularly used are the cellular and Markov chain analysis and their hybrid model called the CA-Markov model $[38,39]$.

Markov chain analysis is a random stochastic modeling approach that is discrete in both time and state. It determines land use changes at two different time periods [40] to project probabilities of land use changes for the future. The underlying assumption here is that the probability of a system being in a certain state at certain time can be determined if its state at an earlier time is known [41]. The known probabilities generated from past changes are applied to predict future changes. The Markov model is suitable for land use modeling as land use data are spatially dependent [30]. Compared to other methods, the Markov model has the ability to predict all multi-directional land use changes among all land use categories available. The model also considers spatial interactions, making it the most preferred model in land use change prediction studies [42]. However, the Markov model is best used for short term projections [4,43] as its analyses are not spatially explicit [44] and do not consider spatial information allocation within each class. In addition, the probabilities of change between landscape states are not constant. Hence, it can offer the right magnitude, but not the right direction of change. This short coming is mitigated by combining the Markov model with a more dynamic and empirical cellular automata (CA) model and commonly referred to as the CA-Markov model. The cellular automata incorporates the spatial dimension and thus adds modeling direction. Thus, the CA-Markov model has the advantage of predicting two-way transitions among the available land use types and is proven to have outperformed regression-based models in predicting land use change [28].

A review of global literature on the use of remote sensing and GIS models for detecting and predicting land use and land cover changes revealed that a significant amount research $[7,11,45-52]$ have used the CA-Markov model. These studies have generated highly credible information on the state of land use changes and their drivers, which can inform better decision making for sustainable 
management of natural resources [19]. Hence, the CA-Markov model was used in this study to predict land use and land cover changes. However, the assessment of land use and land cover change studies by economic levels and geographic locations confirmed fewer such studies were carried out in developing countries and this trend decreases as the countries and regions become more remote. Nepal, a landlocked and remote country in the rugged Himalayan mountain is one such a country where only few studies to detect and predict land use and land cover changes are available [53-58].

Geographically, Nepal is a small developing country located in the rugged landscape of the eastern Himalayas between India to the south and China to the north. Despite the efforts of the government and development agencies to secure Nepal's forests and ecosystem services, Nepal's landscape is fast changing due to deforestation $[59,60]$ and rapid urbanization $[61,62]$. Historical agricultural practices combined with increasing population, aggressive development programs including construction of roads, hydropower plants, topped with expanding urban areas are the main drivers of land use changes and their effects are further exacerbated by the impacts of climate change [63]. A review of studies on land use and land cover changes in Nepal carried out by Paudel, et al. [63] validated these claims, stating that the forest and snow/glacier cover has decreased with increasing crop land and built structures-especially urbanization associated with habitat fragmentation. This is a serious finding, as habitat fragmentation and deforestation—topped with urbanization — pose a critical threat to sustainable development of Nepal's natural resources that provide vital ecosystem services. Similar findings highlighting the unprecedented land use and land cover changes over the last 30 years, especially in urban cores, including Kathmandu were reported in existing studies [61-66]. For instance, in their analysis of historical urban growth patterns in Kathmandu valley, Khanal, et al. [61] report that settlement areas more than doubled between 2000 and 2018. A similar study by Ishatique, et al. [62] reports that urban area expanded by almost $412 \%$ in 30 years and points out the urgent need for major systemic analysis of the urbanization trend and land use and land cover. Based on a 33 years of time series data, Thapa and Murayama [65] observed that the urban built-up areas in Kathmandu valley had a slow trend of growth in the 1960s and 1970s which rapidly increased since the 1980s. In addition, Haack and Rafter [66] in their study to ascertain urban changes in the Kathmandu valley reported an increase of 450\% between 1970 and 2000, confirming the findings reported by other studies [61-65] that the urban growth has expedited significantly since 2000. Despite the immense threats posed by rapid urbanization to ecosystem services and human wellbeing, none of these studies neither focused on the Kathmandu district which is the core of the Kathmandu valley nor predicted future land use and land cover changes, which is important for planners and policy makers. These studies, however, agreed and emphasized the need for more robust scientific studies to deepen the existing understanding of land use and land cover change dynamics [67], to guide politicians, decision-makers and urban planners to design and implement sustainable development plans.

Kathmandu is the crucible of Nepal's socio-economic development and home to over $1,423,515$ people [68], which is projected to double by the year 2030 [69]—mainly due to high rural-urban migration [70]. An open-tourism policy further bloats the city population, putting significant pressure on the environment and urban infrastructure, forcing the city to expand rapidly. Like in any other city, better facilities such as employment, quality education, health, security, and entertainment are resulting in high immigration into Kathmandu. Past studies on Kathmandu valley [61-66] did not abode well for biodiversity conservation and ecosystem services in the district, as their results indicated an increasing deforestation, habitat fragmentation and rapid urbanization. In recent years, rapidly expanding city has been responsible for converting agricultural and forest lands into built-up areas with little planning, resulting in loss of biodiversity and increasing slum settlements especially on the marginal lands such as flood plains that are not only vulnerable to seasonal flooding, but also threatening the riparian ecosystem [61]. While its demonstrated that scientific studies using high resolution images and GIS can provide essential information for planning environmental and economic development programs that are sensitive to achieving social and environmental goals [71,72], no such studies to detect and predict land use and land cover change scenarios for this cosmopolitan district 
has been carried out. To fill this existing gap, this study attempts to detect and predict land use and land cover changes in the Kathmandu district of Nepal by using remote sensing and GIS.

\section{Study Area}

The study was carried out in the landlocked and high-altitude urban district of Kathmandu, Nepal with an area of about $433.6 \mathrm{~km}^{2}$ and located between $27^{\circ} 27^{\prime} \mathrm{E}$ to $27^{\circ} 49^{\prime} \mathrm{E}$ longitude and $85^{\circ} 10^{\prime} \mathrm{N}$ to $85^{\circ} 32^{\prime} \mathrm{N}$ latitude, in the eastern Himalayas. The Kathmandu district is one of the three districts (other two being Lalitpur and Bhaktapur) that constitutes the Kathmandu valley and is the capital city of Nepal. The Kathmandu district is composed of flat plains at $1300 \mathrm{~m}$ above mean sea level surrounded by mountains ranging up to $2800 \mathrm{~m}$ tall [66]. About $20 \%$ of the valley has slopes greater than $20^{\circ}$ [73]. The Kathmandu district has a sub-tropical climate (below $2000 \mathrm{~m}$ ) and temperate climate (above $2000 \mathrm{~m}$ ) and is influenced by south Asian monsoon [67]. The annual average precipitation is about $1407 \mathrm{~mm}$ with monsoon period that lasts from June to September accounting for more than $80 \%$ of its annual precipitation. The annual average temperature in the valley is around $18.1^{\circ} \mathrm{C}$, with some mountain tops remaining under seasonal snow [62]. The main vegetation type of the district is mixed conifer and broadleaved forests at lower elevations, slowly transitioning to conifers to shrub land and occasional snow at higher elevations.

Like many urban areas in the developing countries, Kathmandu is grappling with classic challenges of unplanned and unregulated urban development with poor infrastructure. As the host to Nepal's capital, the Kathmandu district has a large population of over 1,423,515 people compounded by high rural-urban migration and large number of tourists. Over population, urban poverty, and traffic congestion continues to test the limits of city's current infrastructure and threaten ecosystem services and urban wellbeing. Thus, the IIED [70] has designated Kathmandu as one of the 15 most vulnerable cities in the world.

\section{Methodology}

Data processing flow chart (Figure 1) outlines the conceptual framework for detecting and predicting land use and land cover changes in the study area. Key steps in the process include: (i) data acquisition and preparation; (ii) land use and land class classification for 1990 and 2010; and (iii) prediction of land use and land classification in 2030 using the CA-Markov model.

\subsection{Data Acquisitions and Use}

Spatial data and socio-economic data were collected for evaluating the land use and land cover change process. Landsat-5 Thematic Mapper (TM) and Landsat- 8 Operational Land Imager (OLI) images at a resolution of $30 \mathrm{~m}$ were acquired for the years 1990 (01/28/1990: path/row: 141/41) and 2010 (01/13/2010: path/row: 141/41), respectively, to investigate the changes in spatiotemporal patterns of land use and land cover change in the high altitude and landlocked city of Kathmandu in the eastern Himalayas. These two time periods correspond to profound socio-political changes in Nepal that were associated with policy changes including land rights. We selected 1990 because the images were cloud-free and it marked the end of the Panchayat system of governance and the introduction of land tenure system changes. This was followed by the Maoist insurgency from 1996 to 2006 that not only saw the introduction of significant changes in the land ownership system, but also large inflow of immigrants into Kathmandu city. These factors have triggered rapid conversion of land consistently after 2000 [62] and as such detection of land use and land cover changes from pre-Maoist insurgency period of 1990 and post Maoist insurgency period of exacerbated socio-economic development would yield useful information for planners and policy makers. 


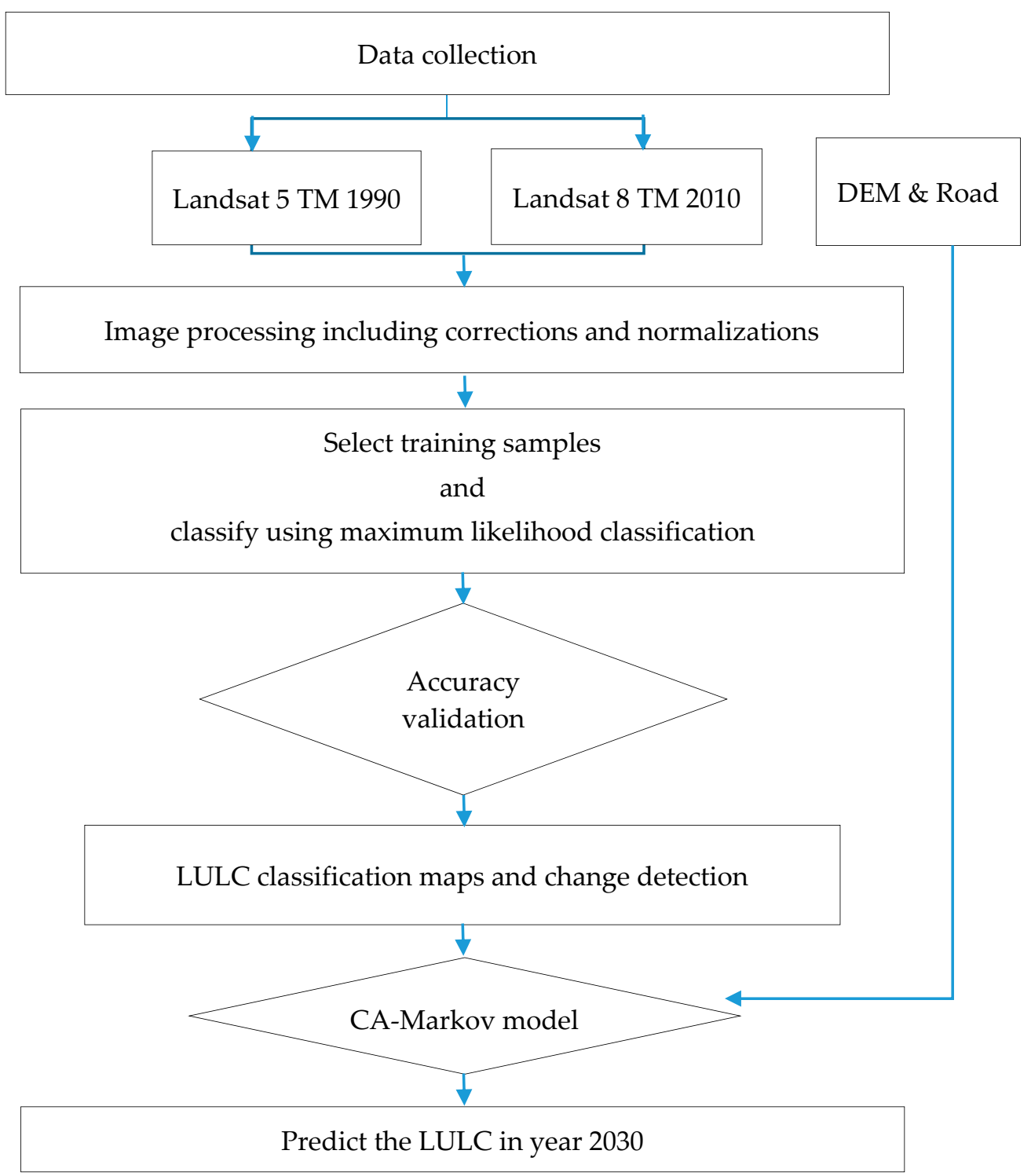

Figure 1. Flow chart of the methodology used.

The satellite images were obtained from the US Geological Survey (USGS) Center for Earth Resources Observation and Science (EROS) found at http://glovis.usgs.gov/. These data sets were imported in ENVI 5.3, ERDAS Imagine version 10.4 and ARC GIS 10.6 satellite image processing software to create a false color composite. Other geospatial data collected from Kathmandu City office include, digital elevation model (DEM) and infrastructure data such as road networks, drainage networks, water bodies, buildings and other important establishments in the city. Additionally, field consultations with select communities, experts and planners from the city office were held to collect relevant socio-economic data and perceptions on the causes of land use and land cover changes including climate change.

\subsection{Image Preprocessing}

Preprocessing of satellite images was required to avoid data distortion or manipulation and to establish direct linkage between data and biophysical phenomena. We used atmospheric and topographic correction (ATCOR3) procedures in ERDAS Imagine to remove haze, atmospheric noise and surface reflectance that could be caused by Earth's rotation [74]. In addition, considering the 
rugged terrain of the eastern Himalayas where the study site was located, terrain correction and temporal normalizations were also carried out.

\subsection{Land Cover Classification}

Both supervised and unsupervised classifications [75-77] were used to identify land use types in the study area. Hyperclustering approach was used as the exact number of spectral classes in the data set was unknown. Considering the Nepal land classification system and the goal of this study, we used google earth observation, other land use maps and familiarity of the study area, to identify seven land use clusters (Table 1), namely; forests (F-broadleaved and conifer forests whether natural or planted are included in this class), shrub land (SL-this class represents the low height woody plants and other bushy vegetation), grassland (GL—grass lands and pastures are included in this class), agricultural land (AL-land dedicated to cultivation of crops, mainly rice, mustard, maize, potatoes and vegetables is included in this class), barren area (BA-this land class is composed of bare lands, rock-strewn, and other exposed soil surfaces that remain devoid of vegetation throughout the year), water bodies (WB - this class is comprised of open water bodies such as lakes, rivers, ponds, streams) and built-up area (BUA - this class represents structures of all types including residential, commercial infrastructure, industrial zones, roads, airports and other paved surfaces). Spectrally similar classes of the identical land use types were merged [66]. The comprehensive set of the spectral class signature was used in the second stage as training data for supervised classification. For data training purposes, about 180 signatures were randomly collected for each year. Simple random sampling was employed to generate these signatures from high resolution google earth engine topped with expert knowledge and familiarity with the study area. The signature points were then tested for statistical similarities [12] which indicated a good degree of similarity-based on spectral distance. Consequently, reasonable signatures were extracted for each land use and land cover types using a triangulation of information from aerial images, google earth, field observation and image enhancement processes. Signatures were considered satisfactory when the confusion between the land uses was minimal [53]

We then carried out supervised classification of all images using the maximum likelihood classifier (MLC) algorithm [78] in the ERDAS Imagine software and GIS. MLC uses a parametric statistical approach to prepare the probability density distribution functions for each individual land use class $[79,80]$. Compared to other methods, MLC is proven to be more accurate, robust and a popular algorithm, as it calculates the total amount of variance and the correlation of the spectral values of different bands according to the specimen. MLC then uses this property for the association of pixels classified into one of the groups and is based on the most similarity between the pixels $[79,80]$. In addition, MLC also reflects the intensity of land use changes and the visual differences in land use types and considers not only the cluster center, but also its shape, size and orientation [81,82].

\subsection{Classification Accuracy Assessment}

Accuracy validation was carried out on the resulting classified imagery using error matrix and kappa index $[83,84]$ to test the precision and accuracy of imagery and comparing them with actual points from the field supplemented by high resolution google earth data. Kappa coefficient was calculated using the formula confirmed and used by Congalton and Green [85];

$$
\text { Kappa coefficient }=\frac{\sum_{i=1}^{k} n_{i i}-\sum_{i=1}^{k} n_{i i}\left(G_{i} C_{i}\right)}{n^{2}-\sum_{i=1}^{k} n_{i i}\left(G_{i} C_{i}\right)}
$$

where, $i$ is the class number, $n$ is the total number of classified pixels that are being compared to actual data, $n_{i i}$ is the number of pixels belonging to the actual data class $i$, that were classified with a class $i, C_{i}$ is the total number of classified pixels belonging to class $i$ and $G_{i}$ is the total number of actual data pixels belonging to class $i$. 
In order to deepen the understanding of major land uses and drivers of their changes and socio-environmental implications, the principal investigator carried out field visits in 2019. During the field visits, field observations and consultations were held with the stakeholders including communities, experts and city officials-as well as collected biophysical and climatic data. Discussions with city planners and locals focused around: evolution of land use, their observations, why the changes and their causes and their perception on socio-environmental resilience. In addition, records of major incidents such as disasters (fire, floods), plantation efforts, urban policy changes, etc. were also noted to relate and/or validate land use and land cover types.

\subsection{Land Use Land Cover Change Analysis}

One of the widely used modeling tools and techniques to detect and predict land use and land cover changes is the CA-Markov model [38]. This model integrates the cellular automata (CA) and Markov chain to forecast land use and land cover change dynamics and characteristics over time [11]. Due to its ability to model both spatial distribution and temporal changes in landscape over time, the model is popularly used by planners and scientists [39] to characterize the dynamics of land use and land cover change, urban growth, modeling watersheds, etc.

We used the CA-Markov model to quantify the extent and magnitude of land use and land cover transition, the rate of change and changed detection matrices [49] for each land use and land cover types between the 1990 and 2010 images. We used ArcGIS cross-tabulation tool functionality to ascertain the transition rates from one land use type to another under certain intrinsic conditions [86]. This determination is possible because land use transitions are proven to follow rules that control the change of a cell's state during a subsequent iteration [87]. These have cellular automata tendencies, which are based on the likely rate of transition from one cell function of its state, cell suitability and its transition probability rule. Finally, land use and land cover change predictions for 2030 were carried out.

\subsubsection{Markov Chain Analysis}

The Markov model is commonly used in detecting and predicting land use and land cover changes [38], because it has the ability to predict all multi-directional land use changes among all land use categories available and considers spatial interactions [42]. The Markov chain analysis is a random stochastic modeling approach that is discrete in both time and state. The Markov chain model defines the land use and land cover transition from one time $\left(t_{1}\right)$ to the next $\left(t_{2}\right)$ to predict future change at a time [40], to project probabilities of land use changes for the future. The underlying assumption here is that the probability of a system being in a certain state at certain time can be determined if its state at an earlier time is known [41]. The known probabilities generated from past changes are applied to predict future changes. The model generates a transition area matrix and a transition probability matrix to predict land use change trends. The Markovian chain analysis is represented as, $S(t, t+1)=P_{i j} \times S(t)$, where, $S(t)$ is the system status at time of $t, S(t+1)$ is the system status at time $t+1$; $P_{i j}$ is the transition probability matrix in a state, which is calculated using the following formula [11,50]:

$$
P_{i j}=\left(\begin{array}{cccc}
P_{11} & P_{12} & \cdots & P_{1 n} \\
P_{21} & P_{22} & \cdots & P_{2 n} \\
\vdots & \vdots & \vdots & \vdots \\
P_{n 1} & P_{n 2} & \cdots & P_{n n}
\end{array}\right) \quad\left(0 \leq P_{i j} \leq 1\right)
$$

where, $P$ is the Markov probability matrix, and $P_{i j}$ stands for the probability of converting from current state $i$ to another state $j$ in next time period. Low transition will have a probability near $(0)$ and high transition probability near (1).

The 1990 land use and land cover image of the Kathmandu district was used as the base $\left(t_{1}\right)$ image while 2010 land use and land cover map as the later $\left(t_{2}\right)$ image in Markov model to obtain 
the transition matrix between 1990 and 2010 for prediction of land use and land cover types in 2030 . Markov chain analysis generates two significant probabilities: (i) transition probability matrix, where the probabilities of transition represent the probability that a pixel of a given class will move to some other cell class in the next time period, and (ii) transition area matrix, which represents the total area (in cells) expected to change from one land use and land cover class to another over the prescribed number of time units. It is generated by multiplying each column in the transition probability matrix by the number of pixels of corresponding class in the later image. The transition probability matrix is expressed in a text file that records the likelihood of moving each land use and land cover category to some other category, while the transition area matrix, also represented in a text file records the number of pixels required to transition from one land use and land cover class to another over the specified number of time unit. The transition area matrix obtained from the two time periods was used as a basis for predicting the future land use and land cover scenarios.

\subsubsection{The CA-Markov Model}

Markov model is suitable for land use modeling as land use data are spatially dependent [30]. However, the Markov model is best used for short term projections [4,43] as its analysis is not spatially explicit [44] and does not consider spatial information allocation within each class and the probabilities of change between landscape states are not constant. Hence, it can offer the right magnitude, but not the right direction of change. This short coming is mitigated by combining the Markov model with a more dynamic and empirical cellular automata model and commonly referred to as the CA-Markov model. Thus, the CA-Markov model is the combination of cellular automata model's ability to stimulate spatial variation in complex systems and the transition probability matrix generated by the cross tabulation of two different images.

Cellular automata is a bottom up dynamic model that incorporates the spatial dimension and thus adds modeling direction [35]. The ability of CA to demonstrate the spatial and dynamic process in simulations are important in land use studies. Thus, the CA-Markov model has the advantage of predicting two-way transitions among the available land use types and is proven to have outperformed regression-based models in predicting land use changes [28]. We used the CA-Markov model to predict 2030 land use and land cover change for the Kathmandu district. Inputs into the CA-Markov models included DEM, road infrastructure data and transition probability matrix and data from 1990 and 2010 of Kathmandu. In order to ensure that the model is reliable in predicting land use and land cover types for 2030, we used Kappa statistics.

\section{Results and Discussion}

\subsection{Classification Accuracy Results}

Accuracy and validation of classification models is an important pre-requisite step in classification, detection and prediction of land use and land cover change studies. The Kappa statistic is a commonly used metric for quantifying the classification accuracy of both the model as well as the user of the model of classification $[88,89]$. The Kappa coefficient values represent the measure of agreement or accuracy between the reference data and the land use and land cover values in the classified image and can take on values from +1 to -1 [85]. Kappa values of $<0$ reflect no agreement, $0-0.2$ as slight, $0.2-0.41$ as fair, $0.41-0.60$ as moderate, $0.60-0.80$ as substantial and $0.81-1.0$ as almost perfect agreement $[89,90]$. According to the classification accuracy test results, the Kappa statistics for the years 1990, 2010 and 2030 were $77 \%, 74 \%, 73 \%$, respectively. These estimates indicate that the classification accuracies were of substantial agreement. This level of agreement is acceptable for classification, detection and prediction of land use and land cover changes. 


\subsection{Analysis of Land Use and Land Cover Types}

Results from classification of the preprocessed satellite images in 1990 and 2010 are presented in Figure 2. We classified 7 land use class types as: forests (F), shrub land (SL), grassland (GL), agricultural land (AL), barren area (BA), water bodies (WB) and built-up area (BUA). Areas and proportions of land under different land use categories as derived from the classification results are also given in Table 1.

\subsubsection{Analysis of Land Use and Land Cover Classes for 1990}

Results of the analysis of the 1990 image (Figure 2) show that forest cover and agricultural land dominated the landscape, with $186 \mathrm{~km}^{2}(42.44 \%)$ and $183 \mathrm{~km}^{2}(41.73 \%)$, respectively. However, the forest cover is confined to the higher elevations away from the core of the city. Agricultural farms are mostly found in between the urban core and the remote forest, indicating its dependence on forest for natural inputs such as water, manure, pasture, etc. and access to markets which are mostly in the city. The third largest land use type is composed of built-up area at $65.09 \mathrm{~km}^{2}(14.83 \%)$ which is mostly located towards the southern part of the district which is the flattest and home to the core of Kathmandu City. There are very little vegetation and agricultural farms in this area signaling reduced ecosystem services. Similar findings were also reported by earlier studies [61,62] for the larger area of Kathmandu valley. Grassland $(0.67 \%)$, shrub land $(0.03 \%)$, water body $(0.11 \%)$, and barren area $(0.18 \%)$ made up the rest of the land area. Such low coverage by grass lands, shrub land and water body is an indication of low levels of ecological diversity and high potential for drought and water shortage. In addition, grassland ecosystems provide important ecological and social services [91] especially for livestock grazing, which is an important livelihood activity [60].
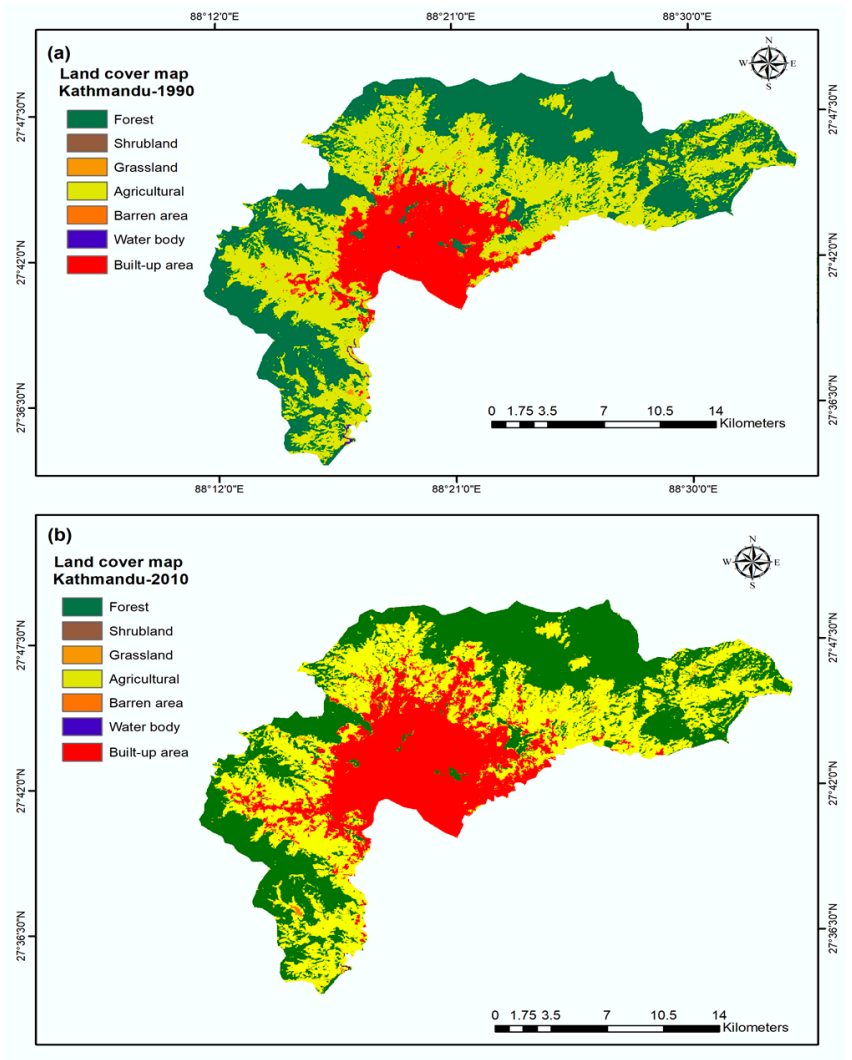

Figure 2. Land use and land cover change (LULC) change map of the Kathmandu district in 1990 (a) and 2010 (b). 


\subsubsection{Analysis of Land Use and Land Cover Classes for 2010}

Compared to 1990 results, findings from the year 2010 shows a significant increase in the cover of build-up area followed by a slight increase in grassland cover. The rest of the land cover classes decreased significantly (Figure 2) with water body, barren area, and shrub land almost disappearing. Despite these decreases, forest land and agricultural land maintained their dominance with a coverage of $168.93 \mathrm{~km}^{2}(38.49 \%)$ and $165.16 \mathrm{~km}^{2}(47.63 \%)$, respectively. However, the built area expanded into the agricultural and forest lands with $99.24 \mathrm{~km}^{2}$ representing over $22 \%$ of the total district land. This represents an increase of almost $8 \%$ increase since 1990 and has sustainable management consequences including degradation of land and ecosystem services. Past studies by Khanal, et al. [61], Ishtiaque, et al. [62] and Paudel, et al. [63] attributed the reduction of agricultural and forest lands to rapid urbanization and lack of stringent policies governing land conversions. Khanal et al. [61] also reported that the rate of urbanization in Kathmandu increased rapidly after the civil war ended in 2006. A slight increase in grassland is probably due to deforestation and abandonment of agricultural land.

\subsection{Analysis of Land Use and Land Cover Class Change Trends between 1990 and 2010}

The land use and land cover class change trend analysis indicate the direction of land class changes based on their respective initial years as a reference [45]. The results (Table 1) show that both forest and agriculture coverage have decreased by $17.28 \mathrm{~km}^{2}(9.28 \%)$ and $17.95 \mathrm{~km}^{2}(9.80 \%)$, respectively. Similar trends were also reported by previous studies in urban areas in Nepal [63] including Kathmandu valley [61,62] and elsewhere in the world [11,45,48,50]. These decreases signal a warning for degrading ecosystem services and increase in food insecurity that could be triggered by unsustainable utilization of forest resources, drought (lack of irrigation water), land conversion to urban and settlement centers and impacts of climate change. The biggest decrease (98\%) by proportion to 1990 is the shrub land coverage which has ecological consequences including loss of biodiversity, soil protection and water retention properties. This topped with loss of water body by $77 \%$ is a serious finding calling for urgent management interventions especially under continuous drying of water sources across the globe due to global warming [29]. In the case of Kathmandu, filling in of water bodies such as canals, riparian zones and wetlands to create space for infrastructure may have exacerbated the rate of water body loss. Decrease in water bodies poses an imminent water crisis for the already water scare city especially under global warming scenarios. Communities especially in the more vulnerable sections such as the slums are being impacted severely by water shortages and often resort to polluted water for domestic. Women and children who are mostly tasked with cooking and washing while men go out to work bear the brunt of these impacts including exposure to water borne diseases. City authorities and planners must urgently implement adaptation and mitigation programs to protect the existing water sources in the city as well as conserve watersheds and water bodies upstream. Such programs must emphasize water conservation programs and water use ethics coupled with stricter penalties for those who do not comply.

Built-up area has expanded by 52.47\% from 1990 (14.83\%) to 2010 (22.61\%), representing a significant increase in area built-up of $34.15 \mathrm{~km}^{2}$. This rapid increase in built-up area confirms past report by the United Nations Department of Economic and Social Affairs [67] and subsequently by other researchers [61-63] who asserted that Kathmandu valley in particular-and Nepal in general-is facing unchecked and unplanned urbanization. It is obvious from the results that land use classes such as forest and agriculture have transitioned into other land uses by the year 2010. Rapid urbanization is mainly responsible for the conversion of agricultural and forest lands into built-up areas. The increase in urban growth has been higher in adjacent areas of the cities and built-up areas along the main roads by creating new cores. Past studies reporting similar findings for Kathmandu valley [61-63] reasoned that the rate of urbanization and its spread outwards from the urban core increased sharply after the civil war ended in 2006, which was followed by reinvigorated development. Increasing of grassland cover $(62.36 \%)$ also shows that forest lands are being degraded and replaced by grass lands. 
Table 1. Composite table of area statistics $\left(\mathrm{km}^{2}\right.$ and\%) of the Kathmandu district in 1990 and 2010.

\begin{tabular}{|c|c|c|c|c|c|c|}
\hline \multirow{2}{*}{ Land Cover Types } & \multirow{2}{*}{$\begin{array}{c}1990 \\
\text { Area }\left(\mathrm{km}^{2}\right)\end{array}$} & \multicolumn{3}{|c|}{2010} & \multirow{2}{*}{$\begin{array}{c}\text { Overall Change }{ }^{1} \\
\text { Area }\left(\mathrm{km}^{2}\right)\end{array}$} & \multirow{2}{*}{$\%$ Change $^{2}$} \\
\hline & & $\%$ & Area $\left(\mathrm{km}^{2}\right)$ & $\%$ & & \\
\hline Forest & 186.21 & 42.44 & 168.93 & 38.49 & -17.27 & -9.28 \\
\hline Shrub land & 0.15 & 0.03 & 0.0027 & 0.00 & -0.15 & -98.20 \\
\hline Grass land & 2.96 & 0.67 & 4.806 & 1.10 & 1.85 & +62.36 \\
\hline Agricultural & 183.11 & 41.73 & 165.16 & 37.63 & -17.95 & -9.80 \\
\hline Barren area & 0.80 & 0.18 & 0.6084 & 0.14 & -0.19 & -23.95 \\
\hline Water body & 0.47 & 0.11 & 0.108 & 0.02 & -0.37 & -77.02 \\
\hline Built-up area & 65.09 & 14.83 & 99.24 & 22.61 & 34.15 & +52.47 \\
\hline Total & 438.79 & 100.00 & 438.86 & 100.00 & 0.07 & \\
\hline
\end{tabular}

${ }^{1}$ indicates overall change in area of different land cover types between 1990 and $2010 .{ }^{2}$ indicates percentage change in land cover types between 1990 and 2010.

\subsection{Land Use and Land Cover Change Transition Matrix from 1990-2010}

The land use and land cover matrix from 1990 to 2010 showed important trends in land use transition from one class to another. The distribution of transition between land use classes were mapped in Figure 3 and the detailed coverage of area transition from one to another classes in Table 2. Overall, a total of $127.26 \mathrm{~km}^{2}$ of land transitioned from one to another class. This represented about $29 \%$ of the total land area with the highest transition recorded from forest to agricultural land ( $43 \%)$. Spatially this change has happened in areas further away from existing urban core. In addition, forest land is also being transitioned into built-up areas $\left(4.67 \mathrm{~km}^{2}\right)$ and grassland $\left(1.92 \mathrm{~km}^{2}\right)$. This trend will threaten biodiversity and ecosystem services as fully functioning forests are cleared. Interestingly, the biggest agricultural land transition is into forest land (40\%), partly due to the commendable government support to encourage private and community forests [92]. This transition has offset the otherwise large conversion of forest land into agricultural land. Compared to forest land, significantly more agricultural land transitioned to built-up area $\left(27.9 \mathrm{~km}^{2}\right)$ with very little area of built-up area converting to either agricultural or forest lands. As discussed in preceding sections, as the urban area expands into the nearby agricultural areas, it has pushed the agricultural areas further into the forests and watersheds. Similar trends have also been reported by Khanal et al. [61] demanding sustainable management of cities including ecosystem-based adaptation pathways.

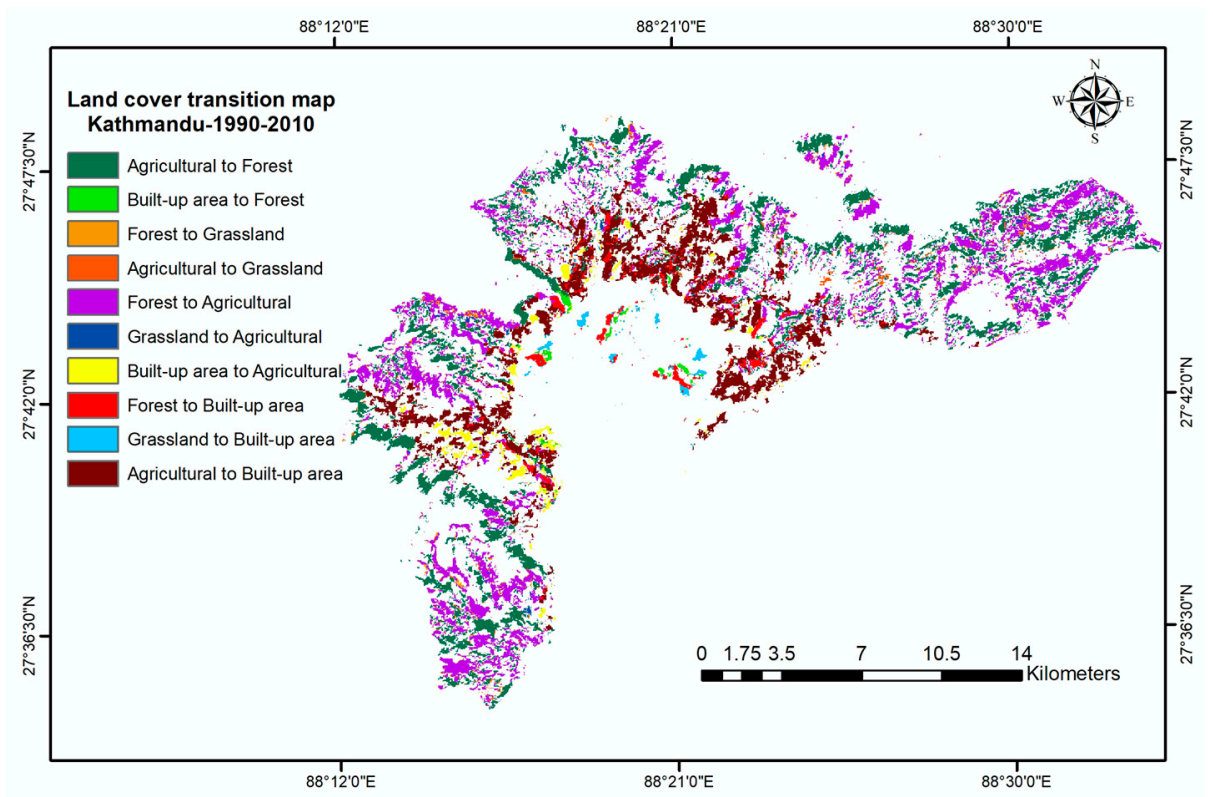

Figure 3. Distribution of the LULC class that transitioned between 1990-2010. 
Table 2. Confusion matrix.

\begin{tabular}{cccccccc}
\hline & Forest & $\begin{array}{c}\text { Shrub } \\
\text { Land }\end{array}$ & $\begin{array}{c}\text { Grass } \\
\text { Land }\end{array}$ & $\begin{array}{c}\text { Agricultural } \\
\text { Land }\end{array}$ & $\begin{array}{c}\text { Barren } \\
\text { Area }\end{array}$ & $\begin{array}{c}\text { Water } \\
\text { Body }\end{array}$ & $\begin{array}{c}\text { Built-up } \\
\text { Area }\end{array}$ \\
\hline Forest & 113.68 & 0.00 & 1.92 & 43.62 & 0.24 & 0.02 & 4.67 \\
Shrub land & 0.04 & 0.00 & 0.00 & 0.06 & 0.00 & 0.00 & 0.03 \\
Grass land & 0.68 & 0.00 & 0.05 & 0.94 & 0.01 & 0.00 & 1.21 \\
Agricultural & 40.29 & 0.00 & 2.44 & 103.10 & 0.29 & 0.05 & 27.90 \\
Barren area & 0.01 & 0.00 & 0.00 & 0.16 & 0.00 & 0.00 & 0.62 \\
Water body & 0.02 & 0.00 & 0.00 & 0.18 & 0.01 & 0.01 & 0.05 \\
Built-up area & 0.98 & 0.00 & 0.06 & 3.31 & 0.03 & 0.00 & 58.92 \\
\hline
\end{tabular}

\subsection{Land Use Land Cover Change Prediction}

The predicted distribution and coverage of different land use and land cover types for the Kathmandu district in 2030 are presented in Figure 4 and Table 3, respectively.

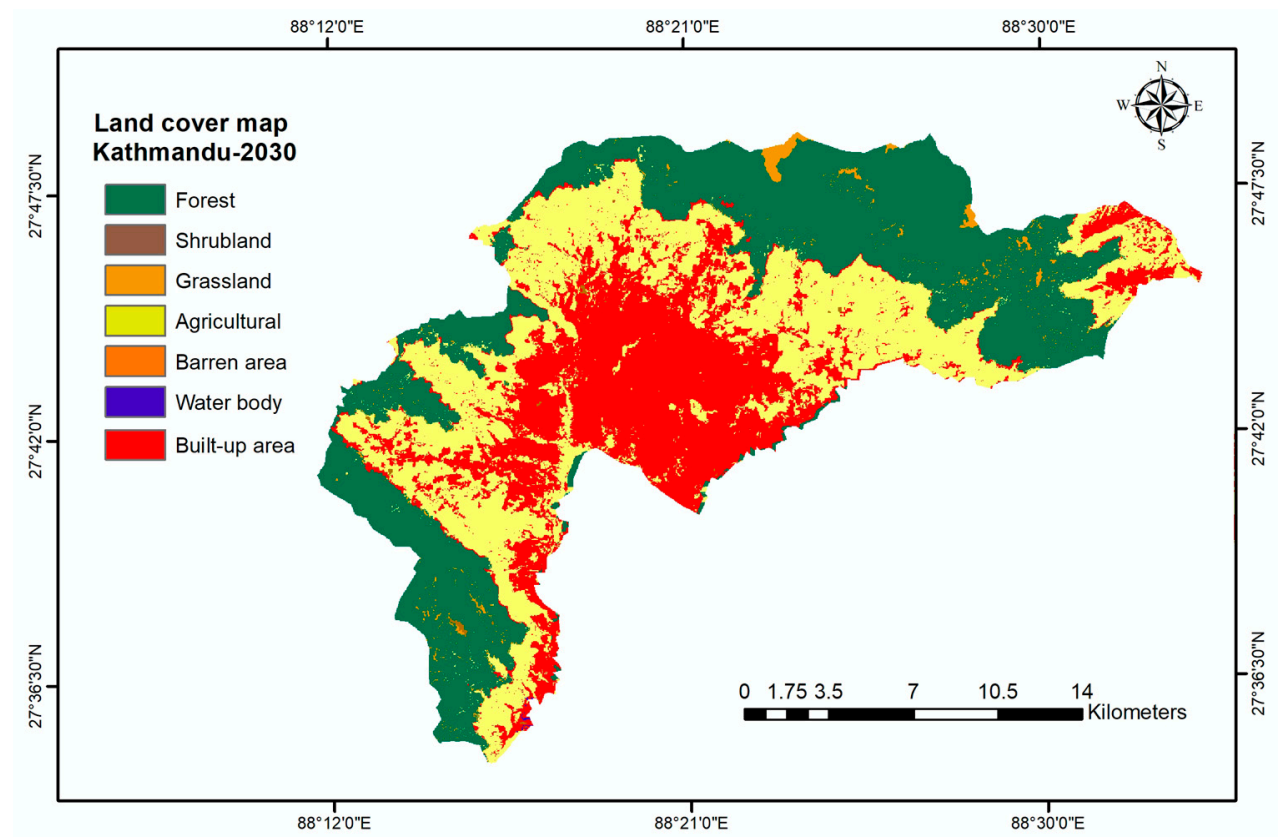

Figure 4. Potential distribution of LULC types of the Kathmandu district in 2030.

Figure 4 shows an overwhelming growth of built-up area outwards indicating the expansion of urban center that is consuming other land classes especially agricultural land, which in turn is consuming forest land. In particular, there is a new growth of built-up area in the eastern tip of the district indicating a growth of a new urban center. Our analysis predicted that the built-up area would expand by about $19 \%$ by 2030 compared to 2010 coverage (Table 3 ). While there have been no prior studies that predicted land use and land cover changes for the Kathmandu district, these trends are not only typical characteristics of the Kathmandu district, but across many global cities especially under the business as usual scenarios [93-95]. Figure 4 also show an increase in grassland by $6 \%$ especially in the previously forested land. While increasing grassland may be beneficial for livestock which is important for agriculture and dairy products, it also indicates deforestation and lack of reforestation efforts. Compared to 2010 areas, predicted agricultural land and shrub land would decrease by about $17 \%$ and $33 \%$, respectively. Under no intervention scenarios, water bodies would have been reduced by $25 \%$, compared to 2010 conditions and as such projects a very bleak future for water and energy security with increased potential for drought. 
Table 3. LULC prediction statistics of the Kathmandu district for 2030.

\begin{tabular}{ccc}
\hline LULC Classes & Area $\mathbf{( k m}^{\mathbf{2}} \mathbf{)}$ & $\mathbf{\%}$ \\
\hline Forest & 144.55 & -14.43 \\
Scrub land & 0.00 & -33.33 \\
Grass land & 5.09 & +5.84 \\
Agricultural & 137.65 & -16.67 \\
Barren area & 0.58 & -4.88 \\
Water bodies & 0.08 & -25.83 \\
Built-up area & 117.65 & +18.55 \\
\hline
\end{tabular}

\section{Conclusions}

Our study used GIS and remote sensing techniques to detect and predict land use and land cover changes in the Kathmandu district over a 30-year period. Our observations in the Kathmandu district exhibits the magnitude and extent of threats and challenges that unplanned urbanization trends occurring at high altitude and land locked locations across the Himalaya will face.

Quantitative evidence from our study also indicate that the Kathmandu district has undergone significant land use and land cover changes since 1990. Forest and agricultural lands followed by built-up area dominated the coverage of the study area during the period from 1990 to 2010. However, rapid increase in urbanization remains a key driver of land use and land cover changes and is taking over agricultural and forest lands. There is also an overwhelming reduction of water bodies which calls for urgent adaptation and mitigation plans. Our prediction analysis did not abode well for water, food and energy securities as well as ecosystem health in the Kathmandu district. Unfortunately, these trends are not only typical characteristics of the Kathmandu district, but across many global cities especially under the business as usual scenarios [93-95]. Such trends if unchecked can result in loss of biodiversity and ecosystem services associated with deteriorating conditions for human well-being, thereby increasing the vulnerability of humans and ecosystem to small changes in the system including climate.

A combination of increasing urban population and their livelihoods, unplanned urbanization, traffic congestion, air pollution and global climate change are responsible for the driving land use and land cover changes. The city with a population of almost 1.5 million people with high rural-urban migration compounded by large number of tourists is exceeding the carrying capacity of its unplanned infrastructure and crippling its ecosystem services. This has resulted in spatial expansion of the urban cores outwards into agricultural land pushing the farmers further into the nearby watersheds and forests thereby exacerbating the loss of biodiversity and ecosystem services which are adversely impacting human wellbeing. The rate of these conversions expedited after 2006, due to rapid urbanization post-civil war coupled with lack of stringent policies governing land conversions and weak monitoring in the face of corruption. Under such circumstances, objective assessment of land use and land cover changes using GIS and remote sensing technology can provide critical information that can help planners plan development more sustainably.

We recommend that Kathmandu City adopt an ecosystem-based approach to addressing socio-economic and ecological issues in the city and mainstream such approaches into their shortand long-term developmental plans. Urban development plans must provide policy and financial support for implementing smart interventions such as: water harvesting and water conservation; planting fruit bearing trees along roads and open spaces; provide safe living quarters for those who are currently living in slums and in vulnerable areas; reduce hard surfaces by converting them into green spaces; improving public transportation that use green fuels; encourage urban agroforestry programs to boost food production; restore and protect water sources and watersheds; forest hillsides; and pass regulations that restrict unplanned development and promote green spaces. 
Finally, our prediction study has not taken externalities such as unpredictable natural and artificial events such as political uprising (war) and disasters such as earthquakes, large fires, etc. in consideration.

Author Contributions: Conceptualization, S.W.W.; methodology, S.W.W.; B.M.G.; M.L.; software, S.W.W.; B.M.G.; M.L.; validation, S.W.W.; R.B.K.; formal analysis, S.W.W.; B.M.G.; M.L.; investigation, S.W.W.; resources, S.W.W.; W.-K.L.; data curation, S.W.W.; B.M.G.; M.L.; writing-S.W.W.; writing-review and editing, R.B.K.; visualization, S.W.W.; B.M.G.; M.L.; supervision, S.W.W.; project administration, S.W.W.; funding acquisition, S.W.W.; W.-K.L. All authors have read and agreed to the published version of the manuscript.

Funding: The research was funded by Environmental GIS/RS Center and Ojeong Eco-Resilience Center (OJERI) of Korea University, South Korea.

Acknowledgments: The authors would like to thank all the city authorities for providing information and urban residents for participating in discussions and sharing perceptions.

Conflicts of Interest: There is no conflict of interest.

\section{References}

1. Shiferaw, H.; Bewlet, W.; Alamirew, T.; Zeleke, G.; Teketay, D.; Bekele, K.; Schaffner, U.; Eckert, S. Implications of land use/land cover dynamics and Prosopis invasion on ecosystem service values in Afar Region, Ethiopia. Sci. Total Environ. 2019, 675, 354-366. [CrossRef]

2. Teketay, D. Deforestation, wood famine, and environmental degradation in Ethiopia's highland ecosystems: Urgent need for action. Northeast Afr. Stud. 2001, 1, 53-76. [CrossRef]

3. Lambin, E.F.; Turner, B.L.; Geist, H.J.; Agbola, S.B.; Angelsen, A.; Bruce, J.W.; Coomes, O.T.; Dirzo, R.; Fische, G.; Folke, C.; et al. The cause of land use and land cover change: Moving beyond the myths. Glob. Environ. Chang. 2001, 11, 261-269. [CrossRef]

4. Lambin, E.F. Modelling and monitoring land-cover change processes in tropical regions. Progr. Phys. Geogr. 1997, 21, 375-393. [CrossRef]

5. Abbas, I.I.; Muazu, K.M.; Ukoje, J.A. Mapping land use-land cover change detection in Kafur local government, Katsina, Nigeria (1995-2008) using remote sensing and GIS. Res. J. Environ. Earth Sci. 2010, 2, 6-12.

6. Screenivasulu, V.; Bhaskar, P.U. Change detection in land use and land cover using remote sensing and GIS techniques. Int. J. Eng. Sci. Technol. 2010, 2, 7758-7762.

7. Hassan, M.M.; Nazem, M.N.I. Examination of land use/land cover changes, urban growth dynamics, and environmental sustainability in Chittagong city, Bangladesh. Environ. Dev. Sustain. 2015, 18, 9672-9678. [CrossRef]

8. Torbick, N.M.; Qi, J.; Roloff, G.J.; Stevenson, R.J. Investigating impacts of land-use land cover change on wetlands in the Muskegon river watershed, Michigan, USA. Wetlands 2006, 26, 1103-1113. [CrossRef]

9. Sala, O.E.; Chapin, F.S.; Armesto, J.J.; Berlow, E.; Bloomfield, J.; Dirzo, R.; Huber-Sanwald, E.; Huenneke, L.F.; Jackson, R.B.; Kinzig, A.; et al. Global biodiversity scenarios for the year 2100. Science 2000, 287, 1770-1774. [CrossRef]

10. Batisani, N.; Yarnal, B. Urban expansion in Centre County, Pennsylvania: Spatial dynamics and landscape transformations. Appl.Geogr. 2009, 29, 235-249. [CrossRef]

11. Liping, C.; Yujun, S.; Saeed, S. Monitoring and predicting land use and land cover changes using remote sensing and GIS techniques-A case study of a hilly area, Jiangle, China. PLoS ONE 2018, 13, e0200493. [CrossRef] [PubMed]

12. Rojas, C.; Pino, J.; Basnou, C.; Vivanco, M. Assessing land-use and cover changes in relation to geographic factors and urban planning in the metropolitan area of concepcion' (Chile). Implications for biodiversity conservation. Appl. Geogr. 2013, 39, 93-103. [CrossRef]

13. Jianchu, X.; Fox, J.; Vogler, J.B.; Yongshou, Z.P.F.; Lixin, Y.; Jie, Q.; Leisz, S. Land use and land cover change and farmer vulnerability in Xishuangbanna Prefecture in Southwestern China. Environ. Manag. 2005, 36, 404-413. [CrossRef] [PubMed]

14. Li, L.; Lu, L.; Kuang, D. Examining urban impervious surface distribution and its dynamic change in Hangzhou Metropolis. Remote Sens. 2016, 8, 265. [CrossRef]

15. Basommi, L.P.; Guan, Q.-F.; Cheng, D.-D.; Singh, S.K. Dynamics of land use change in a mining area: As case study of Nadowli District, Ghana. J. Mt. Sci. 2016, 13, 633-642. [CrossRef] 
16. McCarthy, M.P.; Best, M.J.; Betts, R.A. Climate change in cities due to global warming and urban effects. Geophys. Res. Lett. 2010, 37, L09705. [CrossRef]

17. Kaufmann, R.K.; Seto, K.C.; Schneider, A.; Liu, Z.; Zhou, L.; Wang, W. Climate response to rapid urban growth: Evidence of a human-induced precipitation deficit. J. Clim. 2007, 20, 2299-2306. [CrossRef]

18. Carlson, T.N.; Arthur, S.T. The impact of land cover changes due to urbanization on surface microclimate and hydrology: A satellite perspective. Glob. Planet. Chang. 2000, 25, 49-65. [CrossRef]

19. Lu, D.; Mausel, P.; Brondizio, E.; Moran, E. Change detection techniques. Int. J. Remote Sens. 2003, 25, 2365-2401. [CrossRef]

20. Loveland, T.; Sohl, T.; Stehman, S.; Gallant, A.; Sayler, K.; Napton, D. A strategy for estimating the rates of recent United States land cover changes. Photogramm. Eng. Remote Sens. 2002, 68, 1091-1099.

21. Addo, K.A. Urban and peri-urban agriculture in developing countries studied using remote sensing and in situ methods. Remote Sens. 2010, 2, 497-513. [CrossRef]

22. Rojan, J.; Chen, D. Remote sensing technology for mapping and monitoring land-cover and land-use change. Prog. Plan. 2004, 61, 301-325. [CrossRef]

23. Weng, Q. A remote sensing-GIS evaluation of urban expansion and its impact on surface temperature in the Zhujiang delta, China. Int. J. Remote Sens. 2001, 22, 1999-2014.

24. Coppin, P.; Jonckheere, K.; Nackaerts, K.; Muys, B. Digital change detection methods in ecosystem monitoring: A review. Int. J. Remote Sens. 2004, 25, 1565-1596. [CrossRef]

25. Veldkamp, A.; Lambin, E.F. Predicting land-use change. Agric. Ecosyst. Environ. 2001, 85, 1-6. [CrossRef]

26. Eastman, J.R. IDRISI Guide to GIS and Image Processing. Accessed in IDRISI Selva 1; Clark University: Worcester, MA, USA, 2009; pp. 182-185.

27. Kumar, P.; Jain, S.; Gurjar, B.R.; Sharma, P.; Khare, M.; Morawska, L.; Britter, R. New directions: Can a “blue sky" return to Indian megacities? Atmos. Environ. 2013, 71, 198-201. [CrossRef]

28. Theobald, D.M.; Hobbs, N.T. Forecasting rural land-use change: A comparison of regression- and spatial transition-based models. Geograph. Environ. Model. 1998, 2, 65-82.

29. Lamchin, M.; Lee, W.K.; Jeon, S.W.; Wang, S.W.; Lim, C.H.; Song, C.; Sung, M. Long-term trend and correlation between vegetation greenness a climate variable in Asia based on satellite data. Sci. Total Environ. 2018, 618, 1089-1095. [CrossRef]

30. Overmars, K.P.; de Koning, G.H.J.; Veldkamp, A. Spatial autocorrelation in multi-scale land use models. Ecol. Model. 2003, 164, 257-270. [CrossRef]

31. Hyandye, C. GIS and logit regression model applications in land use and land cover chnge and distribution in Usangu catchment. Am. J. Remoste Sens. 2015, 3, 6-16. [CrossRef]

32. Aitkenhead, M.L.; Alders, H.H. Predicting land cover using GIS, Bayesian and evolutionary algorithm methods. J. Environ. Manag. 2009, 90, 236-250. [CrossRef] [PubMed]

33. Singh, S.K.; Mustak, S.; Srivastava, P.K.; Szabo, S.; Islam, T. Predicting spatial and decadal LULC changes through cellular automata Markov chain models using earth observation datasets and geo-information. Environ. Proces. 2015, 2, 61-78. [CrossRef]

34. Yang, X.; Zheng, X.-Q.; Lv, L.-N. Spatiotemporal model of land use change based on ant colony optimization, Markov chain and cellular automata. Ecol. Model. 2012, 233, 11-19. [CrossRef]

35. Subedi, P.; Subedi, K.; Thapa, B. Application of a hybrid cellular automation-Markov (CA-Markov) model in land change prediction: A case study of saddle creek drainage basin, Florida. Sci. Educ. 2013, 1, 126-132.

36. Stefanov, W.L.; Ramsey, M.S.; Christensen, P.R. Monitoring urban land cover change: An expert system approach to land cover classification of semiarid to arid urban centers. Remote Sens. Environ. 2001, 77, 173-185. [CrossRef]

37. Ralha, C.G.; Abreu, C.G.; Coelho, C.G.C.; Zaghetto, A.; Macchiavello, B.; Machado, R.B. A multi-agent model system for land use change simulation. Remotes Sens. Environ. 2013, 42, 30-46. [CrossRef]

38. Sohl, T.L.; Claggett, P.R. Clarity versus complexity: Landuse modeling as a practical tool for decision makers. J. Environ. Manag. 2013, 129, 235-243. [CrossRef]

39. Zhao, L.; Peng, Z.-R. Lansys: An agent-based cellular automata model of land use change developed for transportation analysis. J. Transp. Geogr. 2012, 25, 35-49. [CrossRef]

40. Baker, W.L. A review of models of landscape change. Landsc. Ecol. 1989, 2, 111-133. [CrossRef]

41. Bell, E.J.; Hinojosa, R.C. Markov analysis of land use change: Continuous time and stationary processes. Socio Econ. Plan. Sci. 1977, 11, 13-17. [CrossRef] 
42. Muller, M.R.; Middleton, J. A Markov model of land-use change dynamics in the Niagara Region. Ontario, Canada. Landsc. Ecol. 1994, 9, 151-157.

43. Sinha, P.; Kumar, L. Markov land cover change modeling using pairs of time series satellite images. Photogramm. Eng. Remote Sens. 2013, 79, 1037-1051. [CrossRef]

44. Sklar, F.H.; Costanza, R. The development of dynamic spatial models for landscape ecology: A review and prognosis. In Ecological Studies, Quantatitive Methods in Landscape Ecology; Turner, M.G., Gardner, R.H., Eds.; Springer: Berlin/Heilderberg, Germany, 1991; Volume 82, pp. 239-288.

45. Appiah, D.O.; Schroder, D.; Forkuo, E.K.; Bugri, J.T. Application of geo-information techniques in land use and land cover change analysis in a peri-urban district of Ghana. Int. J. Geo Inf. 2015, 4, 1265-1289. [CrossRef]

46. Halmy, M.W.; Gessler, P.E.; Hicke, J.A.; Salem, B.B. Land use/land cover change detection and prediction in the north-western coastal desert of Egypt using Markov-CA. Appl. Geogr. 2015, 63, 101-112. [CrossRef]

47. Taubenbock, H.; Wiesner, M.; Felbier, A.; Marconcini, M.; Dech, T.E. New dimensions of urban landscapes: The spatio-temporal evolution from a polynuclei area to a mega-region based on remote sensing data. Appl. Geogr. 2014, 47, 137-153. [CrossRef]

48. Hadi, S.J.; Shafri, H.Z.M.; Mahir, M.D. Modelling LULC for the period of 2010-2030 using GIS and remote sensing: A case study of Tikrit, Iraq. IOP Conf. Ser. Earth Environ. Sci. 2014, 20, 1-11. [CrossRef]

49. Islam, M.S.; Ahmed, R. Land use change prediction in Dhaka city using GIS aided Markov chain modeling. J. Life Earth Sci. 2011, 6, 81-89. [CrossRef]

50. Huang, W.; Luan, Q.; Jiang, Q.; Liu, J.; Liu, H. Detection and prediction of land use change in Beijing based on remote sensing and GIS. The international archives of the photogrammetry. Remote Sens. Spat. Inf. Sci. 2008, 37, 6b.

51. Turner, B.L.; Lambinm, E.F.; Reenberg, A. The emergence of land change science for global environmental change and sustainability. Proc. Natl. Acad. Sci. USA 2007, 104, 20666-20671. [CrossRef]

52. Kalnay, E.; Cai, M. Impact of urbanization and land-use change on climate. Nature 2003, 423, 528-531. [CrossRef]

53. Gao, J. Land Cover Change and Its Relationship with Climate Change in Koshi River Basin of Central Himalaya; Institute of Geographic Sciences and Natural Resources; Graduate University of Chinese Academy of Sciences: Beijing, China, 2012; p. 160.

54. Gautam, A.P.; Webb, E.L.; Shivakoti, G.P.; Zoebisch, M.A. Land use dynamics and landscape change pattern in a mountain watershed in Nepal. Agric. Ecosyst. Environ. 2003, 99, 83-96. [CrossRef]

55. Khanal, N. Land Use and Land Cover Dynamics in the Himalaya: A Case Study of the Madi Watershed, Western Development Region, Nepal; Tribhuvan University: Kirtipur, Nepal, 2002; p. 297.

56. Shrestha, D.P.; Zinck, J.A. Land use classification in mountainous areas: Integration of image processing, digital elevation data and field knowledge (application to Nepal). Int. J. Appl. Earth Observ. Geoinf. 2001, 3, 78-85. [CrossRef]

57. Thapa, G.B. Land use, land management and environment in a subsistence mountain economy in Nepal. Agric. Ecosyst. Environ. 1996, 57, 57-71. [CrossRef]

58. Virgo, K.; Subba, K. Land-Use Change between 1978 and 1990 in Dhankuta District, Koshi Hills, Eastern Nepal. Mt. Res. Dev. 1994, 14, 159-170. [CrossRef]

59. FAO. Statistical Year Book 2014, Asia and the Pacific Food and Agriculture; Food and Agriculture Organization of the United Nations Regional Office for Asia and the Pacific: Bangkok, Thailand, 2014; p. 176.

60. Sharma, B. The Role of Pasture and Fodder Development Program for Landless Farmer in Degraded Forest Land of Agri-Environment and Biodiversity Section; Ministry of Agriculture and Cooperatives: Kathmandu, Nepal, 2006; pp. 89-99.

61. Khanal, N.; Uddin, K.; Matin, M.A.; Tenneson, K. 2019 Automatic detection of spatiotemporal urban expansion patterns by fusing OSM and landsat data in Kathmandu. Remote Sens. 2019, 11, 2296. [CrossRef]

62. Ishtiaque, A.; Shrestha, M.; Chhetri, N. Rapid urban growth in the Kathmandu valley, Nepal: Monitoring land use land cover dynamics of a Himalayan city with landsat imageries. Environments 2017, 4, 72. [CrossRef]

63. Paudel, B.; Zhang, Y.-L.; Li, S.-C.; Liu, L.-S.; Wu, Z.; Khanal, N.R. Review of studies on land use and land cover change in Nepal. J. Mt. Sci. 2016, 13, 643-660. [CrossRef]

64. Rimal, G. Urban growth and land use/land cover change of Pokhara sub-metropolitain city, Nepal. J. Theor. Appl. Inf. Technol. 2011, 26, 1-9. 
65. Thapa, R.B.; Murayama, Y. Examing spatiotemporal urbanization patterns in Kathmandu valley, Nepal: Remote sensing and spatial metrics approaches. Remote Sens. 2009, 1, 534-556. [CrossRef]

66. Haack, B.N.; Rafter, A. Urban growth analysis and modeling in the Kathmandu valley, Nepal. Habitat Int. 2006, 30, 1056-1065. [CrossRef]

67. UN Department of Economics and Social Affairs. World Urbanization Prospects: The 2014 Revision; UNDESA: New York, NY, USA, 2014.

68. World Population Review. Kathmandu City, Nepal. 2020. Available online: https://worldpopulationreview. com/countries/nepal-population/cities/ (accessed on 28 February 2020).

69. Nepal, U. Population Situation Analysis of Nepal; Technical Report; UNFPA Nepal: Lalitpur, Nepal, 2017.

70. International Institute for Environment and Development. Climate Change and the Urban Poor: Risk and Resilience in the 15 of the World's Most Vulnerable Cities; IIED: London, UK, 2009.

71. Dutta, V. Land use dynamics and peri-urban growth characteristics reflections on master plan and urban suitability from a sprawling north Indian city. Environ. Urban. Asia 2012, 3, 277-301. [CrossRef]

72. Suresh, Y.; Balachandar, D.; Murthy, K.R.; Muruganandam, R.; Kumaraswamy, K. Land use/land cover change detection through using remote sensing and GIS technology-a case study of St. Thomas Mount Block, Kancheepuram district, Tamil Nadu. Int. J. Curr. Res. 2011, 3, 501-504.

73. Barnekow Lillesø, J.-P.; Shrestha, T.B.; Dhakal, L.P.; Nayaju, R.P.; Shrestha, R. The Map of Potential Vegetation of Nepal-A forestry/agroecological/biodiversity classification system. In Forest Landscape Development Environment; Prinfo: Aalborg, Denmark, 2005; ISBN 87-7903-210-9.

74. Richter, R.; Schlapfer, D. Atmospheric/Topographic Correction for Satellite Imagery ATCOR-2/3 User Guid; ReSe Applications Schläpfer: Langeggweg, Switzerland, 2014.

75. Wondrade, N.; Dick, O.B.; Tveite, H. GIS based mapping of land cover changes utilizing multitemporal remotely sensed image data in lake Hawassa watershed, Ethiopia. Environ. Monit. Asses. 2014, 186, 1765-1780. [CrossRef] [PubMed]

76. Bui, T.D.; Maier, S.T.; Austin, C.M. Land cover and land use change related to shrimp farming in coastal areas of Quang Ninh, Vietnam using remotely sensed data. Environ. Earth Sci. 2013. [CrossRef]

77. Pabi, O. Understanding land-use/cover change process for land and environmental resources use management policy in Ghana. Geo J. 2007, 68, 369-383. [CrossRef]

78. Lillesand, T.M.; Kiefer, R.W. Remote Sensing and Image Interpretation; Wiley: New York, NY, USA, 1999.

79. Thom, B. Special Issue on the October 1993 Conference on Land-Use and Land-Cover in Australia-Living with Global Change-Preface; John Wiley \& Sons Ltd.: Hoboken, NJ, USA, 1994.

80. Pielke, R.A.; Marland, G.; Betts, R.A.; Chase, T.N.; Eastman, J.L.; Niles, J.O.; Niyogi, D.D.S.; Running, S.W. The influence of land-use changes and landscape dynamics on the climate system: Relevance to climate-change policy beyond the radiative effect of greenhouse gases. Philosophical Transactions of the Royal Society of London. Series A Math. Phys. Eng. Sci. 2002, 360, 1705-1719. [CrossRef]

81. Hailemariam, S.N.; Soromessa, T.; Teketay, D. Land use and land cover change in the Bale Mountain eco-region of Ethiopia during 1985 to 2015. Land 2016, 5, 41. [CrossRef]

82. Molla, M.B.; Ikporukpo, C.; Olatubara, C. The spatio-temporal pattern of urban green spaces in southern Ethiopia. Am. J. Geogr. Inf. Syst. 2018, 7, 1-14.

83. Congralton, R.G. A review of assessing the accuracy of classifications of remotely sensed data. Remote Sens. Environ. 1991, 37, 35-46. [CrossRef]

84. Keshtkar, H.; Voigt, W.; Alizadeh, E. Land-cover classification and analysis of change using machine-learning classifiers and multi-temporal remote sensing imagery. Arab. J. Geosci. 2017, 10. [CrossRef]

85. Congalton, R.G.; Green, K. Assessing the Accuracy of Remotely Sensed Data: Principles and Practices, 2nd ed.; Taylor and Francis Group, LLC: Abingdon, UK, 2009.

86. IDRISI. Andes Guide to GIS and Image Processing. Clark Labs; Clark University: Worcester, MA, USA, 2006.

87. Samat, N.; Hasni, R.; Abdalla, Y.; Elhadary, E. Modelling land use changes at the peri-urban areas using geographic information systems and cellular automata model. J. Sustain. Dev. 2011, 4, 72-84. [CrossRef]

88. Hua, A.K. Land use land cover changes in detection of water quality: A study based on remote sensing and multivariate statistics. J. Environ. Public Health 2017. [CrossRef] [PubMed]

89. Maingi, J.K.; Marsh, S.E. An Accuracy Assessment of 1992 Landsat-MSS Derived Land Cover for the Upper San Pedro Watershed (U.S./Mexico); United States Environmental Protection Agency: Washington, DC, USA, 2002; p. 29. 
90. Manonmani, R.; Suganya, G.M.D. Remote sensing and GIS application in change detection study in urban zone using multi temporal satellite. Int. J. Geomat. Geosci. 2010, 1, 60-65.

91. Zhang, Y.; Qi, W.; Zhou, C.; Ding, M.; Liu, L.; Gao, J.; Bai, W.; Wang, Z.; Zheng, D. Spatial and temporal variability in the net primary production of alpine grassland on the Tibetan Plateau since 1982. J. Geogr. Sci. 2014, 24, 269-287. [CrossRef]

92. Malla, Y.B. Impact of community forestry policy on rural livelihoods and food security in Nepal. Unasylva 2000, 51, 37-45.

93. Sun, C.L.; Wu, Z.F.; Lv, Z.Q.; Yao, N.; Wei, J.B. Quantifying different types of urban growth and the change dynamic in Guangzhou using multi-temporal remote sensing data. Int. J. Appl. Earth Observ. Geoinf. 2013, 21, 409-417. [CrossRef]

94. Pandey, B.; Seto, K.C. Urbanization and agricultural land loss in India: Comparing satellite estimates with census data. J. Environ. Manag. 2015, 148, 53-66. [CrossRef]

95. Hegazy, I.R.; Kaloop, M.R. Monitoring urban growth and land use change detection with GIS and remote sensing techniques in Dhqahlia governorate Egypt. Int. J. Sustain. Built Environ. 2015, 4, 117-124. [CrossRef]

(C) 2020 by the authors. Licensee MDPI, Basel, Switzerland. This article is an open access article distributed under the terms and conditions of the Creative Commons Attribution (CC BY) license (http://creativecommons.org/licenses/by/4.0/). 